\title{
REDACTIONEEL
}

\section{Wvggz: terug naar de tekentafel}

\author{
Prof. mr. J.C.J. Dute
}

Bij de Tweede Kamer ligt al weer zes jaar het Wetsvoorstel verplichte geestelijke gezondheidszorg (Wvggz), de beoogde opvolger van de Wet Bopz voor de sector psychiatrie. We zijn inmiddels drie nota's van wijziging verder. Van zoveel geknutsel wordt een wet doorgaans niet beter. Dat blijkt ook hier weer het geval. Elders in dit nummer plaatst W. Dijkers kritische kanttekeningen bij de tweede nota van wijziging. Mijn conclusie: met deze nota is het wetsvoorstel ontspoord.

Het OM wordt weer de partij die de rechter verzoekt een machtiging af te geven, zoals nu onder de Wet Bopz. Een gotspe. Want als één ding uit de Bopz-evaluaties duidelijk is geworden, dan is het wel dat het OM die rol niet waarmaakt. Dat is natuurlijk niet toevallig. Het OM houdt zich bezig met strafrecht en begrijpt weinig van de zorgsector. Dit plan is dus tot mislukken gedoemd.

Maar het gaat veel verder: het OM wordt de regisseur die bepaalt of het paadje van de verplichte zorg of dat van het strafrecht wordt bewandeld. De schotten tussen verplichte zorg, forensische zorg en strafrecht worden zo veel mogelijk geslecht. Dat lijkt mooi, maar verplichte zorg en strafrecht worden zo wel twee zijden van dezelfde medaille. De regering zegt ook met zoveel woorden dat 'verplichte zorg op de grens van strafrecht ligt' (p. 94) (!). Ik denk dat het goed is om in daarvoor in aanmerking komende strafrechtelijke procedures na te gaan of (verplichte) zorg niet de voorkeur verdient boven strafoplegging. Maar voor het overige dienen beide sectoren strikt gescheiden te blijven. Stigmatisering, met alle consequenties van dien, ligt anders op de loer.

De nieuwe aanpak is in feite een onvervalst stukje incidentenpolitiek. De grondslag daarvan is gelegd door de Commissie-Hoekstra die de moord op Els Borst heeft onderzocht. In haar rapport staat de aanpak van de problematiek van 'verwarde personen' centraal. Maar lang niet iedereen die in aanmerking komt voor verplichte zorg is 'verward', en andersom. Ironisch is bovendien dat de problematiek van 'verwarde personen' nauw samenhangt met het jarenlang bezuinigen op psychiatrische en andere zorgvoorzieningen.

En dan heb ik het nog niet gehad over de observatiemaatregel, de wel erg ruimhartige informatiedeling, de almaar toenemende regeldichtheid, het vervallen van het hoger beroep, het kunnen overrulen van wilsbekwaam verzet bij acuut levensgevaar voor de betrokkene, en zo verder. De Wvggz dreigt meer een probleem dan een oplossing te worden. Ook de kritiek op het Wetsvoorstel zorg en dwang, de andere opvolger van de Wet Bopz, zwelt aan. Het niveau van rechtsbescherming dat dit voorstel biedt, schiet tekort. Het wordt steeds duidelijker dat we met beide wetsvoorstellen op een catastrofe afstevenen. Terug naar de tekentafel dus. Beter ten halve gekeerd dan ten hele gedwaald.

* Jos Dute is hoogleraar gezondheidsrecht aan de Radboud Universiteit te Nijmegen, en lid van de redactie van dit tijdschrift. 